\title{
The influence of changing reward of electronic consumer goods on burglary and theft offences in Western market-based countries in the years prior to and during the crime drop
}

\author{
Liam Quinn* and Joseph Clare (1)
}

\begin{abstract}
It is widely recognised that burglary and theft offence trends have broadly moved in parallel in 'Western' market-based countries since the 1950s. Most researchers have focussed on the trend from the early 1990s onwards, when burglary and theft offence rates plummeted. One major proposed explanation for this trend, relates to improved security. This paper draws on the longitudinal variations in reward of electronic consumer goods to propose a complementary account. This argument is supported by criminological theory, empirical evidence, and historical trends of specific property crime offences. The paper concludes by explaining that reward and security operate in partnership to influence the opportunity for crime, which provides an optimal account for burglary and theft offence trends over the last 40 years.
\end{abstract}

Keywords: Crime opportunity, Crime drop, Reduced reward, Situational crime prevention, Stolen goods markets

\section{Introduction}

Burglary and theft offence trends have broadly moved in parallel in 'Western' market-based countries since the 1950s. Between the 1950s and 1990s burglary and theft offence rates consistently increased, and since the early 1990s these rates significantly decreased and continue to do so (see Farrell et al., 2014; Tonry, 2014, for reviews). While a plethora of factors have been hypothesised to account for this trend, none of them have adequately explained the phenomenon, with improved security arguably among the more coherent explanations to date (Farrell, 2021; Farrell et al., 2014). However, as will be explained in this paper, even the security hypothesis does

*Correspondence: liam.quinn@research.uwa.edu.au School of Law, University of Western Australia, 35 Stirling Hwy, Crawley, Perth, WA 6009, Australia not sufficiently account for the variation in crime rates over time, particularly with respect to the reason for the increase in burglary and theft offence rates between the 1950 s and early 1990s. Drawing on criminological theory, peer-reviewed research, and empirical data, this discussion paper explains why the changing reward of electronic consumer goods complements the security hypothesis in explaining burglary and theft offence trends from the 1950s to the present date.

The impact of the changing reward of electronic consumer goods, specifically, should not be understated. Electronic consumer goods have long comprised the third largest category of goods stolen in domestic burglaries (Office for National Statistics, 2020; Shaw et al., 2015; Wellsmith \& Burrell, 2005), while mobile phones alone have consistently been stolen in over $30 \%$ of all 'theft from the person' incidents for the past 10 years (ONS, 2020). original author(s) and the source, provide a link to the Creative Commons licence, and indicate if changes were made. The images or other third party material in this article are included in the article's Creative Commons licence, unless indicated otherwise in a credit line to the material. If material is not included in the article's Creative Commons licence and your intended use is not permitted by statutory regulation or exceeds the permitted use, you will need to obtain permission directly from the copyright holder. To view a copy of this licence, visit http://creativecommons.org/licenses/by/4.0/. The Creative Commons Public Domain Dedication waiver (http://creativeco mmons.org/publicdomain/zero/1.0/) applies to the data made available in this article, unless otherwise stated in a credit line to the data. 
The two categories of goods that have continually represented a larger proportion of the stolen goods mix are cash and jewellery (ONS, 2020). Cash and jewellery have always been valuable to prospective thieves as they have inherent value. Indeed, one of the more effective rewardreducing phenomena for theft of cash has arguably been the decrease in availability of cash (Delaney et al., 2020), as we shift increasingly towards a cashless society. A recent study has shown a statistically significant and large correlation between cash usage and proportion of incidents in which cash was stolen, both decreasing, between 2007 and 2019 (Quinn \& Clare, in press). Over this same time period, the proportion of incidents in which jewellery was stolen remained stable, testament to its stable (and high) resale price (Shaw et al., 2015), disposability (Ross, 2007), and presumed availability, over time. While it is likely that reduced cash availability contributed to the crime drop, we focus on the changing reward of electronic consumer goods to explain changing burglary and theft offence rates in the time period prior to, as well as during the crime drop. The assumption here, consistent with the theoretical account in the section that follows, is that the increasing (decreasing) reward of electronic consumer goods to prospective thieves, and thus the increasing (decreasing) reward of the overall prospective stolen goods mix, will exert an upward (downward) force on aggregated levels of burglary and theft offences.

Despite reward being a major pillar of the crime as opportunity perspective (Cornish \& Clarke, 2003), and convincing evidence for the association between changing reward and theft of commodity and consumer goods longitudinally (e.g., Draca et al., 2019; Rosenfeld, 2014), there has been a lack of serious consideration given to a central role of the changing reward of electronic consumer goods in driving burglary and theft offence trends between the 1950s and the present date. It is the aim of the present paper to address this gap in the literature. To build this argument this paper begins by establishing a theoretical basis for proposing that longitudinal changes in the reward of burglary and theft offences help to explain changes in their subsequent offence rates. Next, high-level trends from previous published empirical work demonstrating an association between longitudinal variation in the changing reward of burglary and theft offences and burglary and theft offence rates is presented. Following this, Consumer Price Index (CPI) data for a range of electronic consumer goods in the US and UK are compared to domestic burglary rates in the respective locations for the years prior to and during the crime drop. Finally, an original reanalysis of historical trends for specific burglary and theft offences is presented and discussed in the context of the longitudinal variation in reward of these offences.

\section{Theoretical underpinning for the importance of reward}

This section explains how the hypothesis that the changing reward of burglary and theft offences is an important factor affecting longitudinal burglary and theft offence rates is grounded in the crime as opportunity perspective. Namely the CRAVED framework, crime scripts, and the situational crime prevention framework will be discussed. In analysing goods most frequently stolen by thieves, Clarke (1999) determined that 'hot products' are those that are: concealable, removable, available, valuable, enjoyable, and disposable (CRAVED). While the concealability, removability, and availability of goods place physical limitations on their stealing potential, the value, enjoyability, and disposability of goods are qualitative, time-varying attributes that can explain theft rates of goods that consistently meet the physical (concealable, removable, available) attribute requirements for theft over time. Given that the majority of property crime is committed with economic motivations in mind (Cromwell et al., 1991; Wright \& Decker, 1996), the value and disposability, rather than enjoyability, attributes of goods over time are particularly important in explaining why and what goods are stolen. Indeed, Clarke (1999) suggested that the disposability of stolen goods (i.e., the ease with which they can be converted into cash or drugs) is likely the most important attribute affecting the amount a specific good is stolen. Sutton (1998) explained that the demand for stolen goods increases when the legitimate market price of that good increases, meaning that the changing legitimate prices of goods influences their value and disposability. As such, if the concealability, removability, and availability of hot products do not change significantly over time, but their prices consistently increase, then they would be inherently more rewarding to prospective thieves, and theft rates would exhibit a similar increase. Conversely, if the prices of hot products consistently decrease, then they would be inherently less rewarding to prospective thieves, and theft rates would also decrease (meaning they would also lose their labels as hot products).

In the empirical research section that follows, we will present findings on the relationship between changing burglary and theft offence rates and two proxies for changing reward (legitimate prices and inflation). It is important to recognise that while these two constructs and their relationship with changing burglary and theft offence rates have differences-which will be discussed in the following section-ultimately, both represent changing value and disposability of stolen goods, and thus changing reward to offenders over time. Furthermore, while several other economic factors have been raised to explain changing burglary and theft offence rates over 
time, it is only necessary for the purpose of our argument to demonstrate that changing reward has played a significant role in the changing burglary and theft offence rates from the 1950s to the present date. Though results on the relationship between changes in unemployment and burglary and theft offence rates over time have been markedly mixed (see Chiricos, 1987, for a review), changes in unemployment rates have conceivably played a role in changes in property crime at some level. Indeed, this fits with routine activity theory (Cohen \& Felson, 1979) and the crime as opportunity perspective where higher unemployment may increase the presence of capable guardians at home on the one hand, while it may also increase the number of motivated offenders on the other, potentially explaining these mixed results; though the difficulty measuring an appropriate unemployment construct may also have a bearing (Chamlin \& Cochran, 1998). The point here is that other economic conditions have likely impacted burglary and theft rates over time, but if proxies for changing reward such as inflation, and more suggestively, changing prices of electronic consumer goods, are clearly associated with changing burglary and theft offence rates over the entire period from the 1950s to the present date, then the importance of changing reward on these trends needs to be more seriously considered. Moreover, if the changing reward hypothesis is consistent with trends in more specific burglary and theft offences (where another major explanation such as changes in security is not) then this position is bolstered. These two undertakings are the motivations for the next two sections of this paper, but first, the mechanics of how changing reward can impact changing burglary and theft offence rates at an individual level is theoretically examined. This is important as our argument implies that these individual changes aggregate to impact higher level burglary and theft offence trends.

The criminological tool of crime scripts can assist in understanding how the malleable nature of item-specific reward can influence offending decisions, and aggregate to impact overall burglary and theft offence trends. Crime scripts are procedural action sequences followed by offenders during the preparation, commission, and completion of a specific crime (Cornish \& Clarke, 2014). In the case of residential burglary, the crime script involves routinised behaviours for preparation, entering the setting, precondition, target selection, all the way through to the disposal of the stolen goods (Cornish \& Clarke, 2017). Importantly, the crime script can be modified in the event of an offender having difficulty disposing of the stolen goods or receiving an unsatisfactory price for the goods (Cornish, 1994). One possible modification would involve targeting alternative goods believed to be in higher demand or more valuable. Another possible modification is that the crime script is disrupted, the cycle of offending is broken, and the offender desists from that type of crime. This is supported by qualitative offender research showing that the experience of success or failure in disposing of stolen goods is an important determinant to whether novice thieves continue to commit crime (Sutton, 1998). In this way, the impact of increasing prices of electronic consumer goods on burglary and theft offence rates can be understood in terms of the success of these offences reinforcing crime scripts and increasing the volume of these offences. Similarly, the impact of decreasing prices of electronic consumer goods on burglary and theft offence rates can be understood in terms of the desistance of offenders due to ailing stolen goods markets and the disruption of crime scripts.

The impact of the changing reward of burglary and theft offences on burglary and theft offence rates can also be understood in relation to the situational crime prevention framework (Cornish \& Clarke, 2003). The core impetus of the situational crime prevention framework is to reduce crime opportunities by modifying the situational factors surrounding a potential crime. This is achieved by increasing the effort, increasing the risks, reducing the rewards, reducing the provocations, and removing the excuses associated with a crime. These five major mechanisms are proven in the situational crime prevention literature to reduce crime with little or no displacement to other crime types (see Welsh \& Farrington, 1999; Guerette \& Bowers, 2009, for reviews). The changing legitimate market prices of electronic consumer goods directly impacts the resale price of stolen goods, as they are typically sold for a third of the retail value (Ferrante \& Clare, 2006; Sutton, 1998). As such, consistently decreasing prices of goods over time represent a quasi-natural reduced reward market reduction approach, leading to decreasing theft rates of goods. Conversely, increasing legitimate prices of electronic consumer goods over time increases the reward of burglary and theft offences and subsequent offence rates.

\section{Empirical research demonstrating an association between variation in prices of goods and theft rates of goods over time}

Initial evidence that the changing reward of burglary and theft offences has impacted burglary and theft offence rates over time comes from studies measuring the effects of inflation. Among the factors proposed to underlie a positive relationship between inflation and property crime rates includes an increased motivation or reward factor in terms of a market for stolen goods. Inflation rewards property crime offences due to a rising demand for cheap stolen goods, which serves to increasingly incentivise their supply (Allen, 1996; Devine et al., 
1988; Rosenfeld, 2014). Using annual changes in the CPI as a measure of inflation, statistically significant positive relationships between inflation and property crime rates have been reported in the United States (US) for a variety of time periods, including 1947-1972 (Land \& Felson, 1976), 1948-1985 (Devine et al., 1988), 1957-1990 (LaFree \& Drass, 1996), 1959-1992 (Allen, 1996), 19581995 (Ralston, 1999), 1960-2005 (Tang \& Lean, 2007), 1960-2012 (Rosenfeld \& Levin, 2016), and 1977-2007 (Yearwood \& Koinis, 2011). Similar significant positive inflation-property crime relationships have also been reported in France between 1950 and 1997 (Lagrange, 2003), and in a sample of eight 'Western' market economy countries between 1981 and 2010 (Rosenfeld, 2014). These statistically significant relationships between inflation and property crime rates are independent of a range of other socioeconomic conditions included in the models and together, span the years 1947 to 2012. Moreover, the effect is non-trivial. For example, Rosenfeld (2014) calculated that in the eight nations included in the model, burglary rates declined by $3.03 \%$ of their annual average value over the period (1981-2010), but that this would have been a $3.47 \%$ decrease, absent the effects of inflation. The relationship between inflation and property crime rates reported in the literature has been remarkably consistent in its statistical significance and positive directionality. This positive relationship provides an indication that a reward factor is important in affecting property crime rates over time through a changing willingness among consumers to purchase stolen goods. However, inflation is a broad construct that is, among other things, representative of a changing willingness to purchase stolen goods. Other factors associated with changing reward such as changing income inequality might also affect a changing willingness to purchase stolen goods (Rufrancos et al., 2013). As such, to avoid simply relabelling several broad economic indicators under 'changing reward' and claiming that some combination of these factors has produced the property crime trends since the 1950s, a more specific construct of changing reward is necessary. That specific construct is the changing prices of electronic consumer goods over time, and there is good reason to believe it has impacted changing burglary and theft offence rates for the following reasons: (a) there is robust evidence for an association between changing prices and changing property crime rates which suggests aggregate offence rates are responsive to changes in prices of goods, and (b) there are comparable trends between consumer price indices for electronic consumer goods and burglary rates over time.

Evidence for the relationship between the changing reward of property crime and property crime rates comes from time series modelling research that has used a price measure for specific types of goods. Several of these studies have involved measuring the change in price of a particular good and general property crime rates, with an identification strategy that attempts to isolate the effect of reward. For example, D'Este (2014) tested whether changes in the prices of gold impacted rates of stealing offences in areas with a higher concentration of pawnshops. The results of the analysis for the time period 1997-2005 showed a significant positive effect for the interaction between pawnshop concentration and gold price on burglary rates over time. Similarly, the results of the analysis for the time period 2006-2010, when gold prices saw a drastic increase, also showed a significant positive effect for the two variables (D'Este, 2014). Braakmann et al. (2017) similarly found a significant positive relationship between gold prices and burglary rates in areas in the United Kingdom (UK) where it is widely believed that a large amount of gold is stored in homes, for the time period 2011 to 2015 . A time series analysis has also been estimated for the retail price of audio-visual goods and domestic burglary rates in an area in the UK for the time period 1976 to 2005. A significant positive relationship was reported between domestic burglary rates and the real retail price of audio-visual goods over time, with a $10 \%$ decrease in retail price of audiovisual goods associated with an average $2.9 \%$ decrease in domestic burglary rates with a variety of socioeconomic controls in place (Reilly \& Witt, 2008).

Further evidence for the relationship between the changing reward of goods and theft-related property crime rates comes from time series research on the price and theft rates of the same type of good. A recent systematic review identified 18 studies that have tested this relationship (Quinn et al., forthcoming). While the relationship between price and theft of some goods (e.g., copper) has consistently been reported in the literature as statistically significant and meaningful (for examples, see Sidebottom et al., 2011, 2014), a key finding from this review was that the type of good measured was important in interpreting price-theft elasticities. Some goods have CRAVED features other than value that attenuate any relationship between price and theft, whereas the more prevalent targets of theft appear to be more sensitive to changing prices (Quinn et al., forthcoming). Indeed, the most convincing empirical evidence for the relationship between changing prices and changing theft rates of consumer goods likely underestimates the strength of the relationship for this reason. The results of the time series analysis for a panel of 44 consumer goods between 2002 and 2012, indicated that a 10\% change in the relative price of a good was associated with a $3.5 \%$ change in theft-related property crime for a good (Draca et al., 2019), which the authors suggested accounted for 
approximately $10-15 \%$ of the crime drop between 2002 and 2012. Overall, these empirical research findings suggest there is a strong reason to believe that the changing prices of hot products are associated with changing theft rates for the same hot products-and in some instances changing burglary or theft rates overall (for examples, see Reilly \& Witt, 2008; Draca et al., 2019). Most importantly for the present hypothesis, this research suggests that aggregate burglary and theft offence rates are responsive to changes in prices of hot products such as electronic consumer goods.

A relationship between changing prices of electronic consumer goods and burglary and theft offence rates makes sense in the context of the changing sales landscape between 1950 and the present date. In Western market-based countries, prices of consumer goods saw steep increases in the 1960s, surged in the 1970s, and peaked in the early 1980s, at the same time property crime rates did (Rosenfeld, 2014). This was a time period that saw the introduction of the first televisions (TVs), videocassette recorders (VCRs), computers, and mobile phones to the market among other high-value electronic consumer goods. Prices of consumer goods have also broadly been decreasing since the early 1990 s when property crime rates have also decreased (Rosenfeld, 2014).

Our argument is that changes in prices of electronic consumer goods drove the increase in burglary and theft offence rates in the years before the crime drop, and the decrease in these offence rates during the crime drop. As such, it is pertinent to present data that supports this contention. Below we present CPI data for different electronic consumer goods categories and compare these trends to domestic burglary rates in the US and UK, for the years prior to and during the crime drop. Unfortunately, much of the research into historical crime trends is hampered by a lack of available data and inconsistencies in recording practices over time for the data that is available (Ariel \& Bland, 2019). As such, the crime trends presented throughout the remainder of this paper will be focussed on available data from the Crime Survey of England and Wales (CSEW), the US National Crime Victimisation Survey (NCVS) and the Australian Crime Victimisation Survey. Importantly, crime victimisation survey data are widely recognised as the most consistent and reliable form of crime data (Farrell et al., 2014; Lauritsen et al., 2016; Tilley \& Tseloni, 2016). Similarly, publicly available longitudinal price data for electronic consumer goods are lacking. We settle for CPI data for different electronic consumer goods categories in the US (Bureau of Labor Statistics) and UK (ONS). Although the CPI comprises a composite measure of changing prices of the specified goods in each category relative to changes in the quality of these goods over time, we believe it provides a good indication of changing reward of electronic consumer goods over time.

As shown in Fig. 1, the US CPI values for televisions and audio equipment remained relatively stable at the same time household burglary rates did in the US between 1973 and 1981 (Bureau of Justice Statistics, 2019; Bureau of Labor Statistics, 2021a, 2021b). Around 1981 the rates of household burglary plummeted and from then until 2019 remained in a broadly downward trajectory (BJS, 2019). This same pattern can be seen for the CPI values for televisions and audio equipment (BLS, 2021a, 2021b). Indeed, the correlation coefficients for the relationships between household burglary rates and the percentage change in CPI values for televisions and audio equipment from 1973 until 2019 were both statistically significant and large at $r=0.95(p<0.001)$ and $r=0.85$ $(p<0.001)$, respectively.

The same general trends can be seen for the UK CPI values for audio-visual equipment and number of domestic burglaries in England and Wales between 1988 and 2020 (ONS, 2020, 2021). As depicted in Fig. 2, the rate of domestic burglaries was still climbing until it peaked in the early 1990s. During this same time period, the CPI values for audio-visual equipment remained reasonably stable at their high relative price index value, indicating a potentially high resale value. From the early 1990s onwards, both the rate of domestic burglaries and audiovisual equipment $C P I$ values then trended comparably downwards until 2020. Indeed, the correlation coefficient for the relationship between domestic burglary counts and percentage change in CPI values for audio-visual equipment from 1987 to 2020 was statistically significant and large at $r=0.85(p<0.001)$.

Considering the crime drop period specifically, there are US CPI data available from 1997 onwards for personal computers and photographic equipment, in addition to the data already presented for televisions and audio equipment. As depicted in Fig. 3, the CPI values for televisions, personal computers, audio equipment, and photographic equipment all trend downwards over the same period that US household burglary rates have (BJS, 2019; BLS, 2021a, 2021b, 2021c, 2021d). Moreover, as highlighted in Fig. 3, these downward trends for CPI values of electronic consumer goods are in contrast to the increasing trend for all CPI items over the same time period (BLS, 2021e).

\section{Original reanalysis of historical trends for specific property crime offences}

There appears to be a theoretical and empirical basis to believe that the changing reward of burglary and theft offences is associated with burglary and theft offence rates between 1950 and the present date. To test the role 


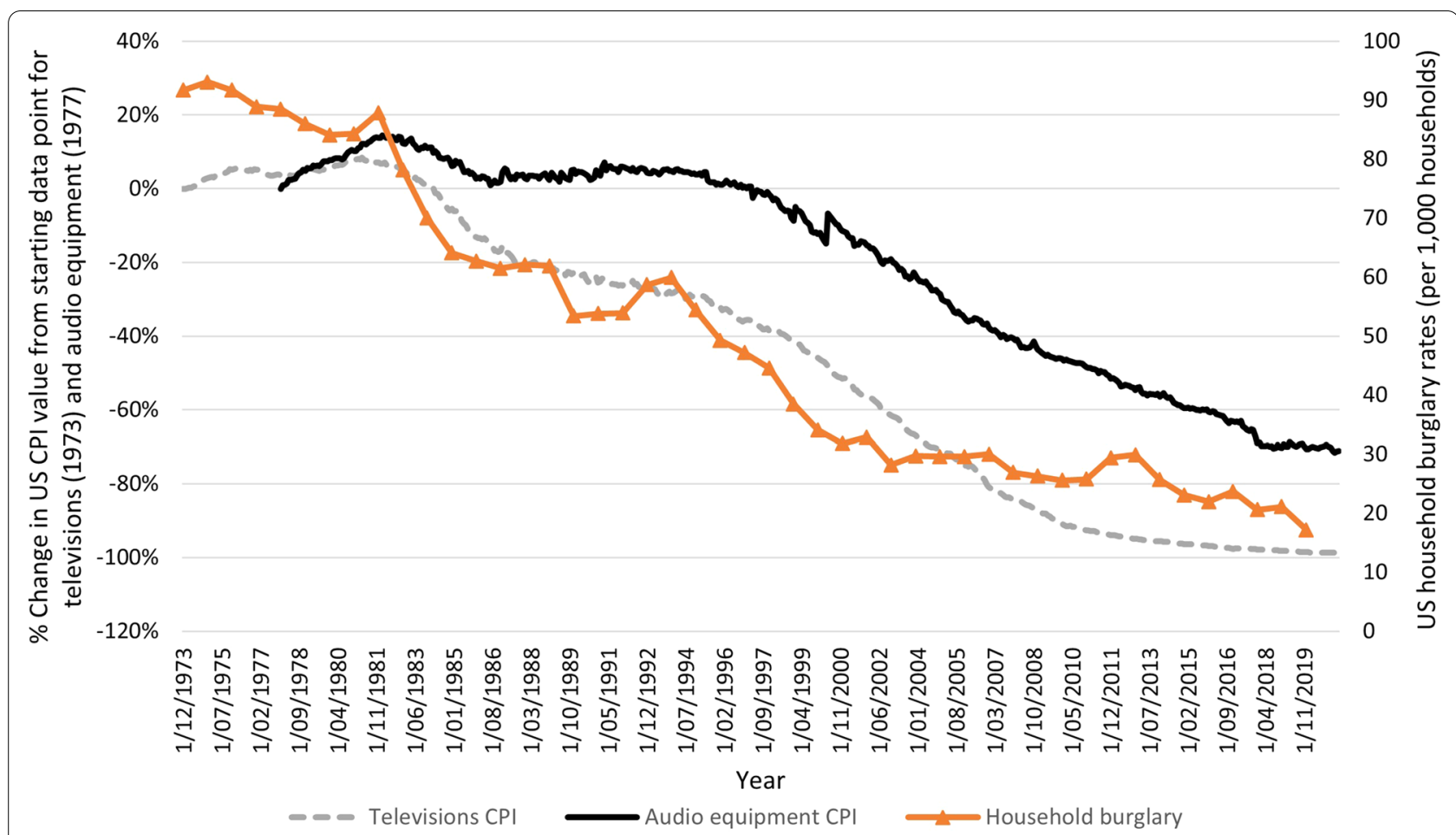

Fig. 1 Rates of household burglaries reported in the National Crime Victimisation Survey (US) between 1973 and 2019 compared to the percentage change in US Consumer Price Index (CPI) values for televisions and audio equipment from the starting data point for televisions (1973) and audio equipment (1977). CPI data are indexed 1997 $=100$

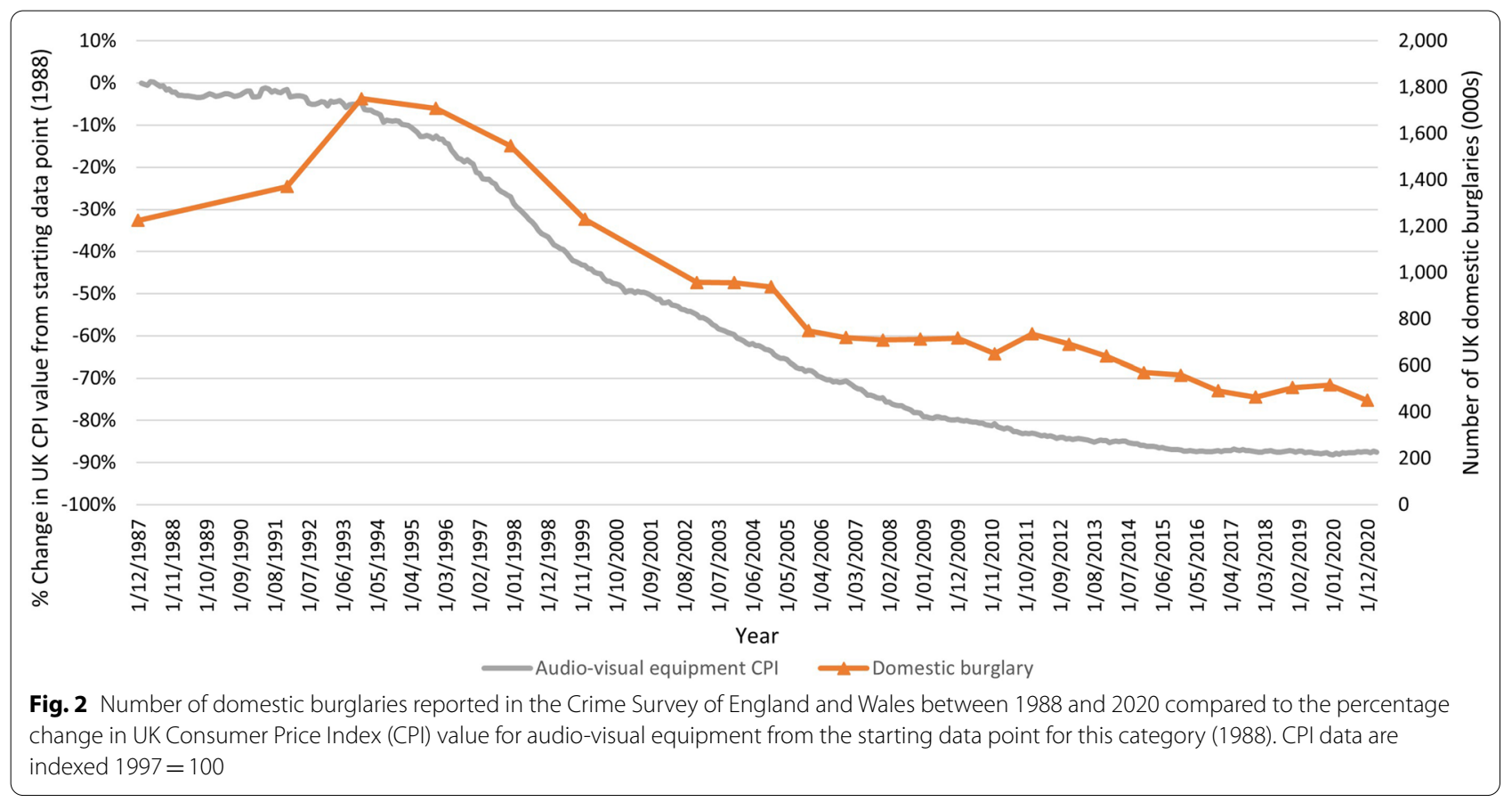




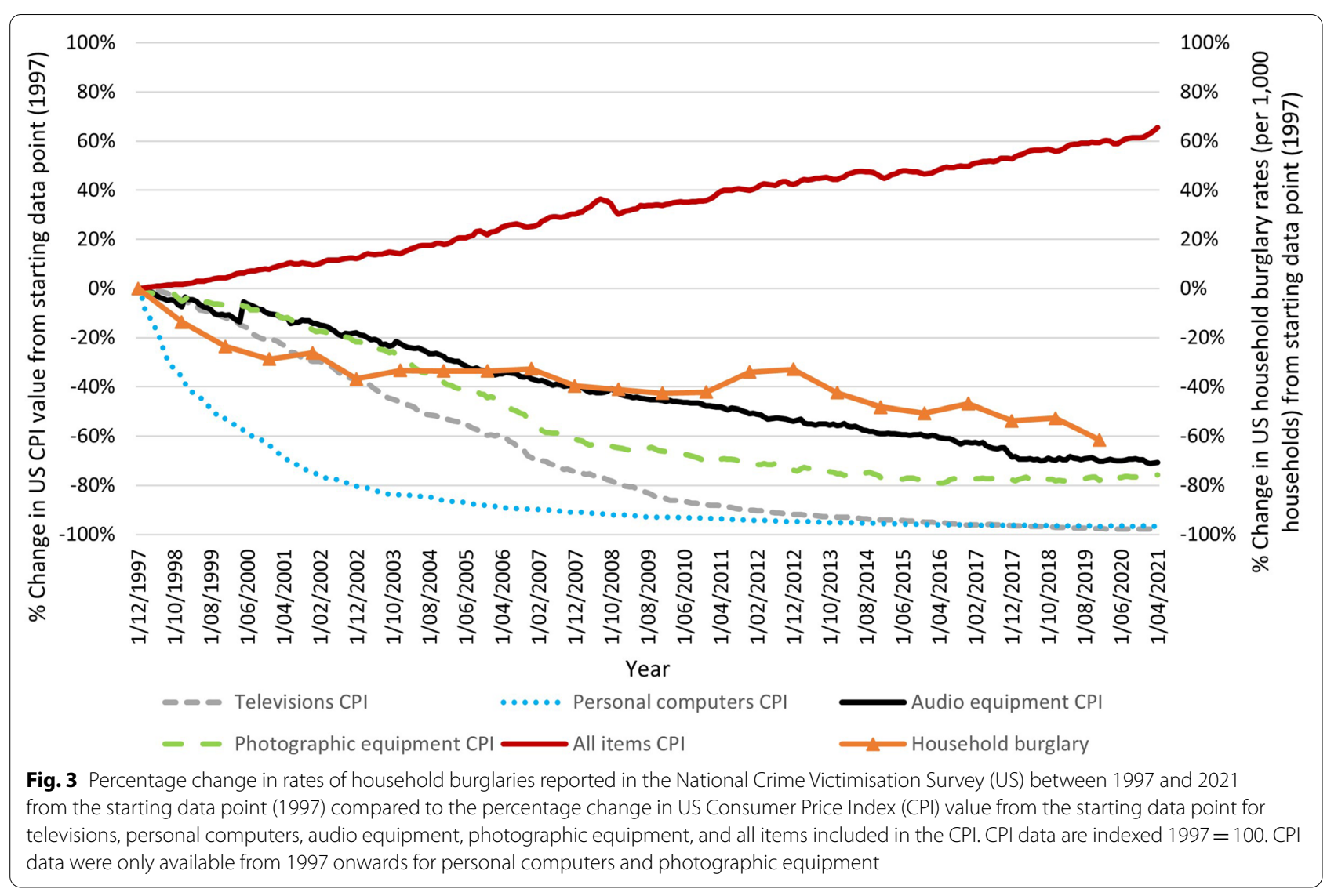

of reward further, trends for specific burglary and theft offences in the years prior to and during the crime drop can be examined. The picture that emerges from these data is consistent with the argument that the changing reward of burglary and theft offences has played a significant role in burglary and theft offence rates between 1950 and the present date.

While the number of overall theft offences has decreased substantially during the crime drop, more specific theft offences exhibit different trends. As such, it is important to provide a theory for the crime drop that is consistent with crime trends of different stealing offences. To begin with, two major property crime offences that drive the overall crime drop trend are vehicle-related theft offences and domestic burglary (Fig. 4). There is robust evidence to suggest that vehicle-related theft trends are driven in large part by improved security (Farrell et al., 2011), which the present paper supports as one factor contributing to the crime drop phenomenon. Indeed, this would explain the particularly sizeable and sudden sharp decrease for vehicle-related theft offences relative to other offences during the crime drop.

If improved security was also the most significant driver of the decrease in domestic burglary rates during the crime drop, then it is reasonable to expect that the proportion of burglaries with entry would decrease, while the proportion of attempted burglaries would increase. However, according to the CSEW, the proportion of each of these remained stable between 1981 and 2020 (ONS, 2020), as depicted by the trend lines in Fig. 5. This same stability in proportions of attempted burglaries and burglaries with entry is demonstrated for crime victimisation data from the US between 1993 and 2003 when household burglary rates substantially decreased (BJS, 2019, see Fig. 6). Furthermore, during the years preceding 1993 when rates of household burglaries in the US were already decreasing, the proportion of these burglaries which were successful shows an increasing trend, while the proportion of attempted burglaries shows a decreasing trend. This is inconsistent with the notion that improvements in security during this time solely drove the decrease in household burglaries.

Alternatively, if reduced reward played a role in the decrease in domestic burglary rates with entry during the crime drop, then it is reasonable to expect that the proportion of burglaries with loss would decrease, while the proportion of burglaries without loss would increase. As depicted by the trend lines in Fig. 7a, this appears to be 


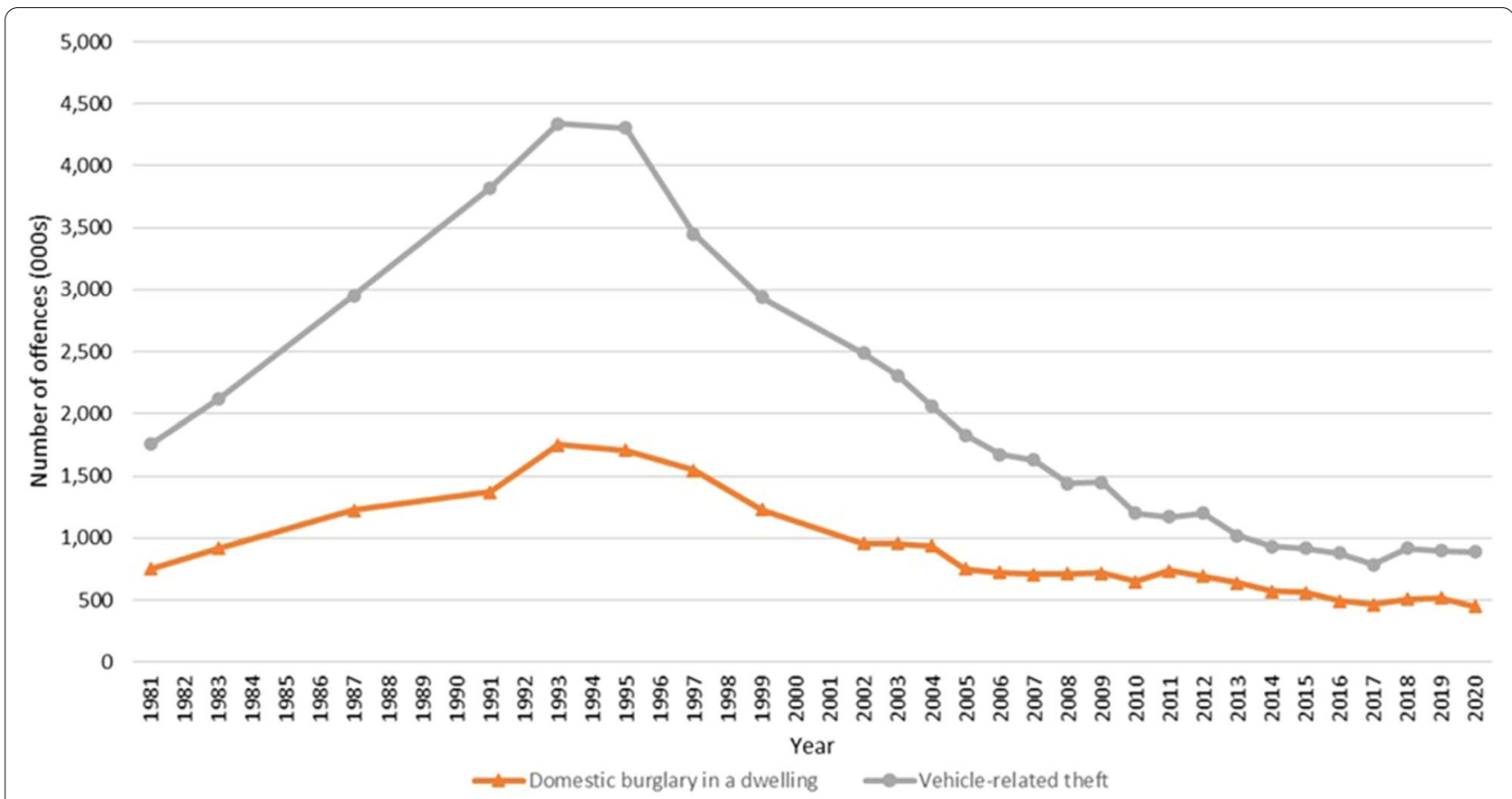

Fig. 4 Number of vehicle-related theft offences and domestic burglaries reported in the Crime Survey of England and Wales between 1981 and 2020

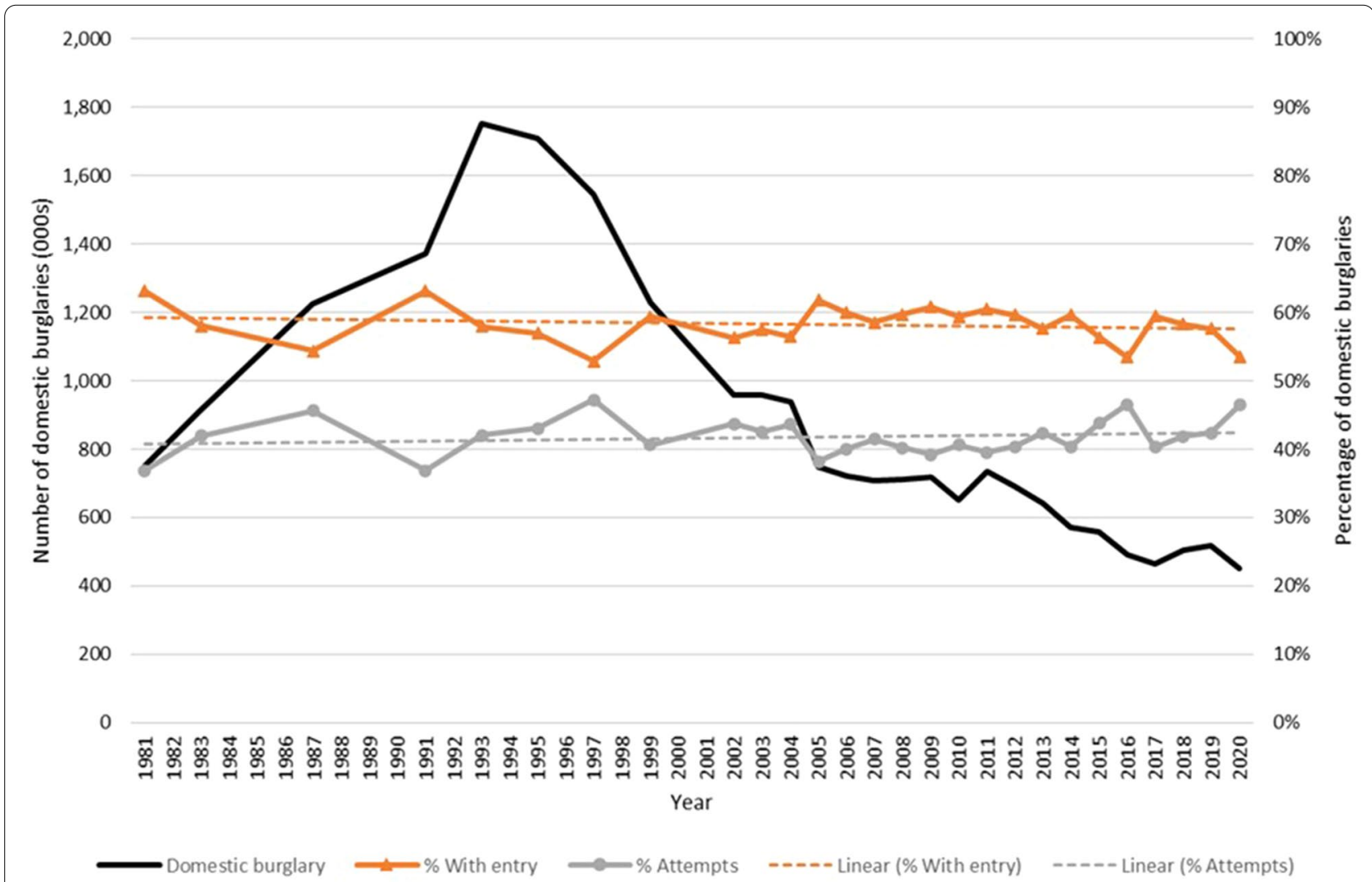

Fig. 5 Number of domestic burglaries reported in the Crime Survey of England and Wales between 1981 and 2020 compared to the percentage of burglaries with entry and percentage of attempted burglaries, with linear trend lines for each 


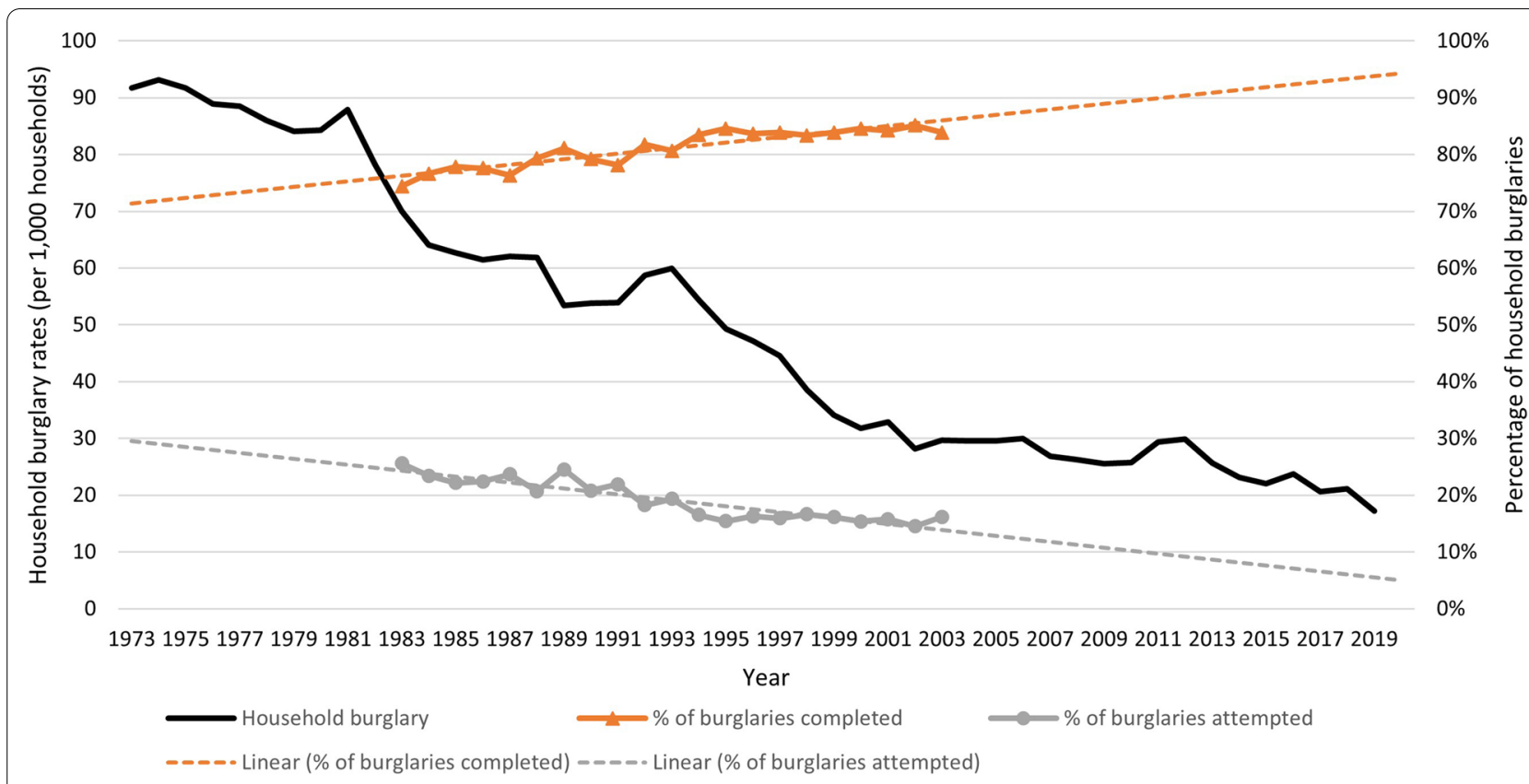

Fig. 6 Rates of household burglaries reported in the National Crime Victimisation Survey (US) between 1973 and 2019 compared to the percentage of burglaries with entry and percentage of attempted burglaries, with linear trend lines for each. Data were unavailable for percentage of burglaries with entry and percentage of attempted burglaries for all years of the survey

the case for both, according to CSEW data (ONS, 2020). During the years of the crime drop, the proportion of burglaries in which the offender entered a dwelling but did not steal any goods increased, while the proportion of burglaries in which the offender entered a dwelling and stole some goods decreased. This same trend is shown with the data that are available from the Australian Crime Victimisation survey (Australian Bureau of Statistics, 2020), for the years 1993 to 2019, as depicted in Fig. 7b.

One reasonable interpretation of these trends is that, over time, offenders have gradually found fewer rewarding goods to steal. This fits with the decreasing prices of electronic consumer goods over the years of the crime drop, which once made up the third major category of stolen goods behind cash and jewellery (Thompson, 2017; Wellsmith \& Burrell, 2005). Indeed, once highvalue, easily disposable electronic goods such as audio equipment, VCRs, TVs, and computers (Wellsmith \& Burrell, 2005) have all but disappeared from the domestic burglary stolen goods mix (ONS, 2020). As mentioned previously, an alternative but complementary factor is the reduced availability of the traditionally most stolen item: cash (Quinn \& Clare, in press). Given the ubiquitous use of bank cards and their impact on people being less likely to store cash in the home, the availability of the most rewarding target of theft has diminished. For example, the share of in-person payments made in cash by Australian consumers was around $74 \%$ in 2007, but down to $48 \%$ in 2019 with consumers continuing to switch to electronic payment methods (Delaney et al., 2020).

Several theft offences have exhibited similar decreasing trends over the years of the crime drop, but the nature of the offences are such that it appears unlikely improved security is the sole cause. Figure 8 shows the CSEW crime trends for 'other theft of personal property' between 1981 and 2020. 'Other theft of personal property' comprises offences where the theft occurs away from the home and there is no force used, theft where there is no direct contact between the victim and offender, and theft where the victim was not holding or carrying the items when they were stolen (ONS, 2020). If the cause of the crime drop was only greater security, this decrease in 'other theft of personal property' does not appear to fit because the widespread improvements in household and vehicular security are clearly not in play here.

'Other household theft' offences also follow the same trajectory as the crime drop that other offences exhibit from the early 1990s onwards. However, 'other household theft' comprises offences within and outside a dwelling by people who were entitled to be there (ONS, 2020). Again, improvements in household security do not appear to be relevant in the declines in this stealing offence, due to the offenders not needing to overcome any security to get inside. A parsimonious alternative explanation for these offence trends involves the reduced reward of stealing electronic consumer goods. 
(a)

1,200

$100 \%$

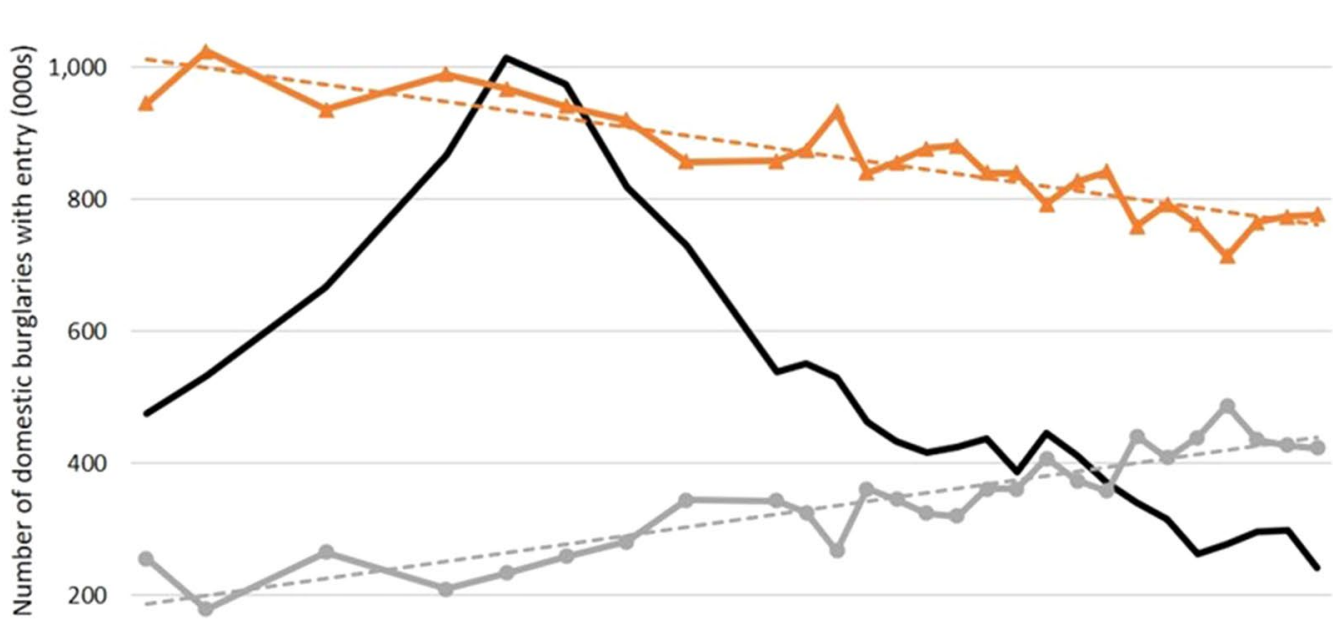

$90 \%$

$80 \%$

$70 \%$

$60 \%$

$50 \%$

$40 \%$

$30 \%$

$20 \%$

$10 \%$

0

$0 \%$

19811983198519871989199119931995199719992001200320052007200920112013201520172019

(b)

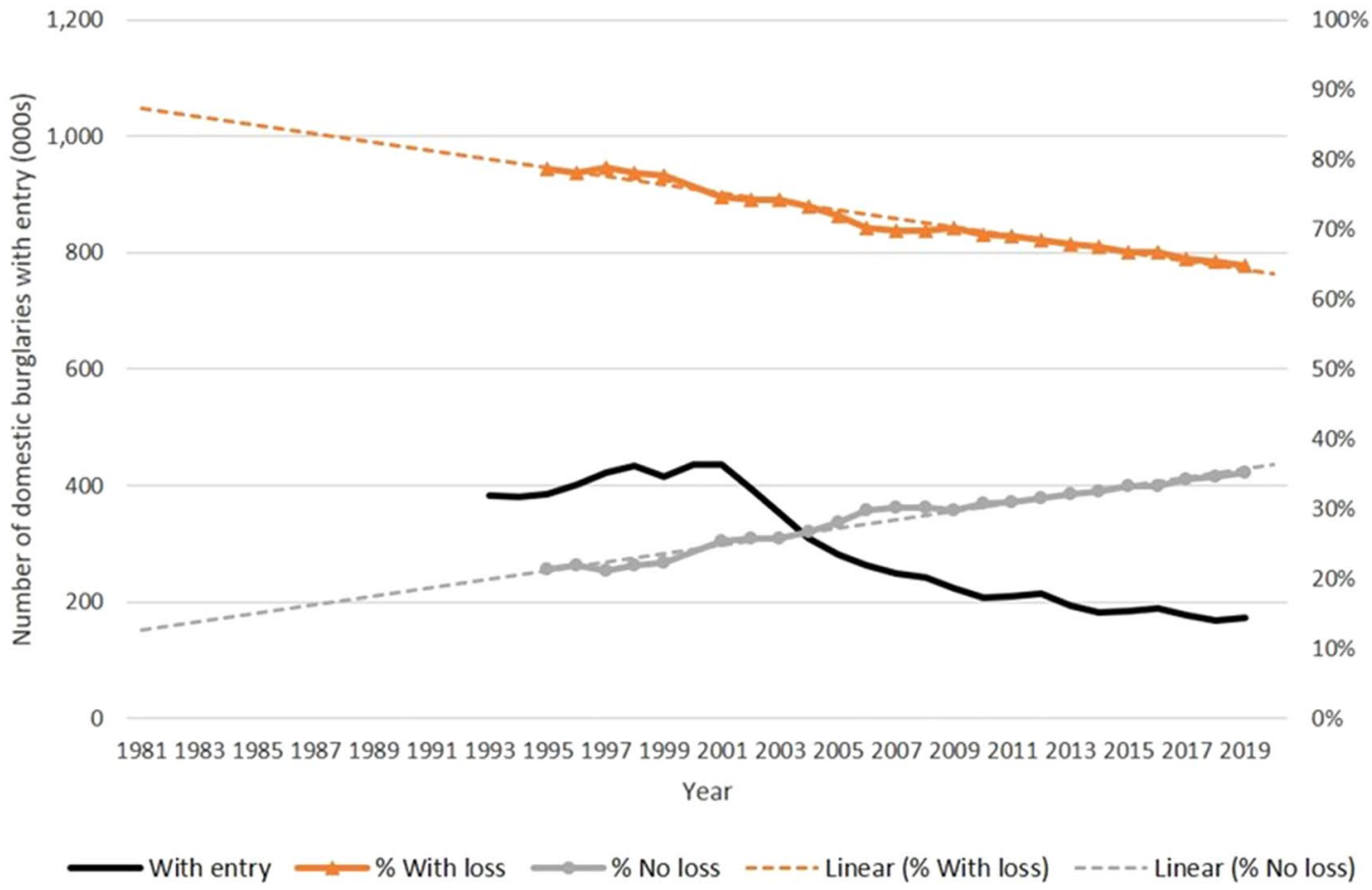

Fig. 7 a Number of domestic burglaries with entry reported in the Crime Survey of England and Wales between 1981 and 2020 compared to the percentage of those burglaries with loss and without loss, with linear trend lines for each. $\mathbf{b}$ Number of domestic burglaries with entry reported in the Crime Victimisation Survey (Australia) between 1993 and 2019 compared to the percentage of those burglaries with loss and without loss, with linear trend lines for each 


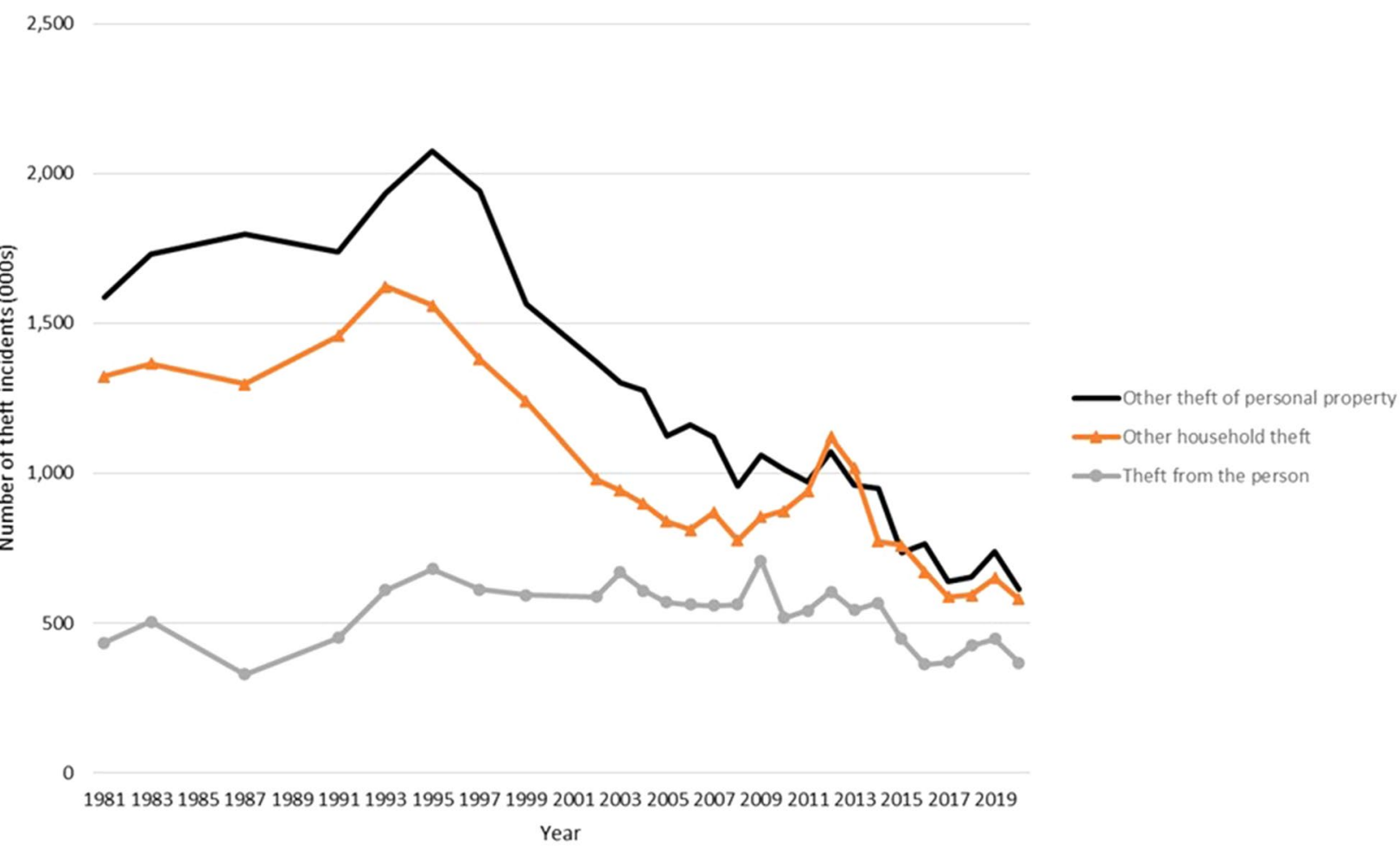

Fig. 8 Number of 'other theft of personal property','other household theft', and 'theft from the person' offences reported in the Crime Survey of England and Wales between 1981 and 2020

Additionally, the reduced storage of cash in homes is consistent with the trends of 'other household theft', while the phenomenon of people carrying less cash on their person is consistent with the trends of 'other theft of personal property'.

By way of comparison, the number of 'theft from the person' offences have not shown a clear decreasing trend over the years of the crime drop (ONS, 2020). Instead, the number of offences appear to have remained largely stable between 1995 and 2014, at which point they began to decrease (see Fig. 8). Theft of mobile phones occurs in the vast majority of 'theft from the person' offences (ONS, 2020). Mobile phones are widely owned, with the number of mobile phone subscriptions surpassing the UK population in 2006 (Office of Communications, 2006) and continuing to outnumber the UK population to the present date (Office of Communications, 2020). Given that mobile phones tend to be carried on the person, this means that they are widely available to prospective thieves. Additionally, trends in theft of specific makes and models of mobile phones are demonstrably influenced by more than simple availability, as measured by sales and ownership levels (Home Mailley et al., 2008; Office, 2014). This is certainly suggestive of the consistently fastmoving legitimate mobile phone market sustaining the reward of mobile phone theft, and by extension, 'theft from the person' offences over time.

Additionally, despite cash use declining overall, it is still reasonable to presume that offenders would be able to steal more cash from a person when compared to a dwelling. Indeed, people are unlikely to intentionally leave cash or their mobile phones unattended, which may explain the relative stability of the number of 'theft from the person' offences compared to the sizeable decrease in the number of 'other theft of personal property' offences during the crime drop. From 2014 onwards there has been a significant decrease in mobile phone thefts (ONS, 2020). One possible reason for this is the reduced reward for stealing mobile phones due to their increasingly cheaper average prices. However, a more likely reason is the reduced reward for stealing mobile phones due to improvements in phone security, such as blacklisting of stolen handsets and increased hardware and software security to prevent use and reprogramming once stolen (Home Office, 2014; Shaw et al., 2015). Importantly, while the security hypothesis highlights target hardening to prevent theft of a good (Farrell et al., 2014), for example, the implementation of electronic immobilisers and central deadlocking systems meant that motor vehicles could no longer be stolen in the first instance leading to 
sharp decreases in crime, these types of phone 'security' reduce the disposability of a good by rendering them less valuable or even worthless at the point of disposal (once they have already been stolen). This is an example of an artificial reward-reduction intervention which is consistent with the changing reward hypothesis. In other words, the decreasing prices of electronic consumer goods are associated with the long-term decreases in burglary and theft offence rates, but the implementation of security improvements or reward-reduction initiatives can more sharply decrease these offence rates. In this way improvements in security and a reduced reward of property crime go hand in hand to impact property crime rates.

\section{Conclusions}

As stated in the introduction, it is not the intention of this paper to posit that the changing reward of electronic consumer goods is the only factor causing the burglary and theft offence trends prior to and during the crime drop. Instead, it is argued that the changing reward is a contributing factor to the phenomenon, along with changes in effort and risk (i.e., security and routine activities) over time. This is consistent, and indeed what would be expected, according to the crime opportunity perspective (Felson \& Clarke, 1998) and the situational crime prevention literature. Building on the strong case presented by Farrell et al. (2014) for the role of increased security on the crime drop, we suggest that the increased reward of electronic consumer goods during the years that burglary and theft offence rates were increasing, and reduced reward during the crime drop, complements these findings to suggest a more rounded crime opportunity explanation. Indeed, the changing reward hypothesis provides a more coherent explanation for why burglary and theft offences increased between the 1950s and early 1990s. At the very least, the evidence presented here suggests that further investigation of the role of the changing reward of electronic consumer goods on burglary and theft offences for the years prior to and during the crime drop is warranted.

To further test the role of changing reward on burglary and theft offence rates over time, future research should investigate this association in non-Western countries where property crime rates are still high. Such crossnational research could also provide important insights into the causes of the crime drop in 'Western' countries, by establishing the similarities and differences between them. For example, in some non-Western countries it is likely there is less even distribution of security across households and a greater use of cash, as well as differing demand dynamics in stolen goods markets. Additionally, future research should test the association between changing prices of goods and theft rates of goods for years prior to and during the crime drop. Finally, as with previous literature examining these issues, the present paper was limited in the data available to compare trends of specific property crimes, future research should test this hypothesis with a more extensive and varied range of crime data and sources.

This paper demonstrates the clear relevance of reward to understanding burglary and theft offence trends. This research is strongly supported by relevant criminological theory, has demonstrated support from previous published work, and presents data from the UK, US, and Australia in a convincing way. Importantly, risk and effort (in terms of security) can work effectively in partnership with reward as compatible leavers to pull in preventing crime, meaning that this argument supports and extends the already important work that emphasises security in understanding why crime has declined.

\begin{abstract}
Abbreviations
BJS: Bureau of Justice Statistics; BLS: Bureau of Labor Statistics; CPI: Consumer Price Index; CRAVED: Concealable, removable, available, valuable, enjoyable, disposable; CSEW: Crime Survey of England and Wales; NCVS: National Crime Victimization Survey; ONS: Office for National Statistics; TV: Television; UK: United Kingdom; US: United States; VCR: Videocassette recorder.
\end{abstract}

\section{Acknowledgements}

The authors would like to thank the anonymous reviewers for their helpful comments to improve the manuscript.

Authors' contributions

Both authors read and approved the final manuscript.

Funding

No outside funding was used to support this work.

Availability of data and materials

Not applicable.

\section{Declarations}

Competing interests

The authors declare that they have no competing interests.

Received: 8 March 2021 Accepted: 18 August 2021

Published online: 28 August 2021

\section{References}

Allen, R. C. (1996). Socioeconomic conditions and property crime: A comprehensive review and test of the professional literature. American Journal of Economics and Sociology, 55(3), 293-308. https://doi.org/10.1111/j.15367150.1996.tb02311.x

Ariel, B., \& Bland, M. (2019). Is crime rising or falling? A comparison of policerecorded crime and victimization surveys. Emerald Publishing Limited.

Australian Bureau of Statistics. (2020). Crime victimisation, Australia. Australian Bureau of Statistics. Retrieved from https://www.abs.gov.au/statistics/ people/crime-and-justice/crime-victimisation-australia/latest-release.

Braakmann, N., Chevalier, A., \&Wilson, T. (2017). Asian gold-expected returns to crime and thieves behaviour. Working Paper. Retrieved from http://confe rence.iza.org/conference_files/WoLabConf_2018/chevalier_a1143.pdf. 
Bureau of Justice Statistics. (2019). National Crime Victimisation Survey. Washington, DC: Bureau of Justice Statistics. Retrieved from https://www.bjs. gov/index.cfm?ty=dcdetail\&iid=245\#Publications_and_products.

Bureau of Labor Statistics. (2021a). CPI for All Urban Consumers (CPI-U): Televisions in U.S. city average, all urban consumers, not seasonally adjusted. Washington, DC: Bureau of Labor Statistics. Retrieved from https://beta. bls.gov/dataViewer/view/timeseries/CUUR0000SERA01.

Bureau of Labor Statistics. (2021 b). CPI for All Urban Consumers (CPI-U): Audio equipment in U.S. city average, all urban consumers, not seasonally adjusted. Washington, DC: Bureau of Labor Statistics. Retrieved from https://beta. bls.gov/dataViewer/view/timeseries/CUURO000SERA05.

Bureau of Labor Statistics. (2021c). CPI for All Urban Consumers (CPI-U): Photographic equipment in U.S. city average, all urban consumers, not seasonally adjusted. Washington, DC: Bureau of Labor Statistics. Retrieved from https://beta.bls.gov/dataViewer/view/timeseries/CUUR0000SS61023.

Bureau of Labor Statistics. (2021d). CPI for All Urban Consumers (CPI-U): Personal computers and peripheral equipment in U.S. city average, all urban consumers, not seasonally adjusted. Washington, DC: Bureau of Labor Statistics. Retrieved from https://beta.bls.gov/dataViewer/view/timeseries/CUURO O0OSEEE01.

Bureau of Labor Statistics. (2021e). CPI for All Urban Consumers (CPI-U): All items in U.S. city average, all urban consumers, not seasonally adjusted. Washington, DC: Bureau of Labor Statistics. Retrieved from https://beta.bls.gov/ dataViewer/view/timeseries/CUUROOOOSAO.

Chamlin, M. B., \& Cochran, J. K. (1998). Causality, economic conditions, and burglary. Criminology, 36(2), 425-440. https://doi.org/10.1111/j.17459125.1998.tb01254.x

Chiricos, T. G. (1987). Rates of crime and unemployment: An analysis of aggregate research evidence. Social Problems, 34(2), 187-212. https://doi.org/ $10.2307 / 800715$

Clarke, R. V. (1999). Hot products: Understanding, anticipating, and reducing demand for stolen goods. Police Research Series, Paper 112, Policing and Reducing Crime Unit. Research Development and Statistics Directorate. Home Office.

Cohen, L. E., \& Felson, M. (1979). Social change and crime rate trends: A routine activity approach. American Sociological Review, 44, 588-608.

Cornish, D. B. (1994). The procedural analysis of offending and its relevance for situational prevention. Crime Prevention Studies, 3, 151-196.

Cornish, D. B., \& Clarke, R. V. (2003). Opportunities, precipitators and criminal decisions: A reply to Wortley's critique of situational crime prevention. Crime Prevention Studies, 16, 41-96.

Cornish, D. B., \& Clarke, R. V. (2014). The reasoning criminal: Rational choice perspectives on offending. Transaction Publishers.

Cornish, D. B., \& Clarke, R. V. (2017). The rational choice perspective. In R. Wortley \& M. Townsley (Eds.), Environmental criminology and crime analysis crime science series (2nd ed., pp. 21-47). London and New York: Routledge. Retrieved from https://books.google.com.au/?hl=en.

Cromwell, P. F., Olson, J. N., \& Avary, D. A. W. (1991). Breaking and entering: An ethnographic analysis of burglary. Sage.

Delaney, L., McClure, N., \& Finlay, R. (2020). Cash use in Australia: Results from the 2019 Consumer Payments Survey. Reserve Bank of Australia Bulletin. Retrieved from https://www.rba.gov.au/publications/bulletin/2020/jun/ pdf/cash-use-in-australia-results-from-the-2019-consumer-paymentssurvey.pdf.

D'Este, R. (2014). The effect of stolen goods markets on crime: Evidence from a quasi natural experiment. Working Paper. Retrieved from https://ageco nsearch.umn.edu/record/270415/.

Devine, J. A., Sheley, J. F., \& Smith, M. D. (1988). Macroeconomic and socialcontrol policy influences on crime rate changes, 1948-1985. American Sociological Review, 53(3), 407. https://doi.org/10.2307/2095648

Draca, M., Koutmeridis, T., \& Machin, S. (2019). The changing returns to crime: Do criminals respond to prices? The Review of Economic Studies, 86(3), 1228-1257. https://doi.org/10.1093/restud/rdy004

Farrell, G. (2021). Forty years of declining burglary in the United States: Explanation and evidence relating to the security hypothesis. Security Journal. https://doi.org/10.1057/s41284-021-00284-4

Farrell, G., Tilley, N., \& Tseloni, A. (2014). Why the crime drop? Crime and Justice, 43(1), 421-490. https://doi.org/10.1086/678081

Farrell, G., Tseloni, A., Mailley, J., \& Tilley, N. (2011). The crime drop and the security hypothesis. Journal of Research in Crime and Delinquency, 48(2), 147-175.
Felson, M., \& Clarke, R. V. (1998). Opportunity makes the thief. Police Research Series, Paper 98. Policing and Reducing Crime Unit. Research, Development and Statistics Directorate. London: Home Office.

Ferrante, A., \& Clare, J. (2006). "Known" burglars and the stolen goods market in Western Australia: research report. Western Australia: Office of Crime Prevention, Department of Premier and Cabinet.

Guerette, R. T., \& Bowers, K. J. (2009). Assessing the extent of crime displacement and diffusion of benefits: A review of situational crime prevention evaluations. Criminology, 47(4), 1331-1368.

Home Office. (2014). Reducing mobile phone theft and improving security. UK Home Office: Behavioural Insights Team. Retrieved from https://www.bi. team/wp-content/uploads/2015/07/HO_Mobile_theft_paper_050914_ FINAL.pdf.

LaFree, G., \& Drass, K. A. (1996). The effect of changes in intraracial income inequality and educational attainment on changes in arrest rates for African Americans and whites, 1957 to 1990. American Sociological Review. https://doi.org/10.2307/2096396

Lagrange, H. (2003). Crime and socio-economic context. Revue Française De Sociologie, 44(5), 29-48. https://doi.org/10.3917/rfs.445.0029

Land, K. C., \& Felson, M. (1976). A general framework for building dynamic macro social indicator models: Including an analysis of changes in crime rates and police expenditures. American Journal of Sociology, 82(3), 565-604. https://doi.org/10.1086/226354

Lauritsen, J. L., Rezey, M. L., \& Heimer, K. (2016). When choice of data matters: Analyses of US crime trends, 1973-2012. Journal of Quantitative Criminology, 32(3), 335-355.

Mailley, J., Garcia, R., Whitehead, S., \& Farrell, G. (2008). Phone theft index. Security Journal, 21(3), 212-227.

Office of Communications. (2006). The Communications Market 2006, 3 Telecommunications. August 2006, Office of Communications. Retrieved from https://webarchive.nationalarchives.gov.uk/20160703015014/ http://stakeholders.ofcom.org.uk/market-data-research/market-data/ communications-market-reports/cm06/.

Office of Communications. (2020). The Communications Market 2020, Summary of UK telecoms metrics. September 2020, Office of Communications. Retrieved from https://www.ofcom.org.uk/research-and-data/ multi-sector-research/cmr/cmr-2020.

Office for National Statistics. (2020). Crime in England and Wales: Year ending March 2020. Office for National Statistics. Retrieved from https://www. ons.gov.uk/releases/crimeinenglandandwalesyearendingmarch2020.

Office for National Statistics. (2021). CPI INDEX 09.1: Audio-visual equipment and related products 2015=100. Retrieved from https://www.ons.gov.uk/ economy/inflationandpriceindices/timeseries/d7cs/mm23.

Quinn, L., \& Clare, J. (in press). Longitudinal variations in availability and disposability of specific makes and models of hot products associated with variations in corresponding stealing counts. Current Issues in Criminal Justice.

Quinn, L., Clare, J., Lindley, J., \& Morgan, F. (forthcoming). The relationship between variation in price and theft rates of consumer and commodity goods over time: A systematic review. Unpublished manuscript. University of Western Australia.

Ralston, R. W. (1999). Economy and race: Interactive determinants of property crime in the United States, 1958-1995: Reflections on the supply of property crime. American Journal of Economics and Sociology, 58(3), 405-434. https://doi.org/10.1111/j.1536-7150.1999.tb03295.x

Reilly, B., \& Witt, R. (2008). Domestic burglaries and the real price of audiovisual goods: Some time series evidence for Britain. Economics Letters, 100(1), 96-100. https://doi.org/10.1016/j.econlet.2007.11.005

Rosenfeld, R. (2014). Crime and inflation in cross-national perspective. Crime and Justice, 43(1), 341-366. https://doi.org/10.1086/677665

Rosenfeld, R., \& Levin, A. (2016). Acquisitive crime and inflation in the United States: 1960-2012. Journal of Quantitative Criminology, 32(3), 427-447. https://doi.org/10.1007/s10940-016-9279-8

Ross, K. (2007). Diamond and jewelry industry crime. FBI Law Enforcement Bulletin, 76, 17. Retrieved from https://heinonline.org/.

Rufrancos, H., Power, M., Pickett, K. E., \& Wilkinson, R. (2013). Income inequality and crime: A review and explanation of the time-series evidence. Sociology and Criminology. https://doi.org/10.4172/2375-4435.1000103

Shaw, O., Morgan, N., Mineva, I., Hoare, J., \& Stevenson, R. (2015). Crime and the value of stolen goods. Research Report 81. Home Office: London. 
Retrieved from https://assets.publishing.service.gov.uk/government/ uploads/system/uploads/attachment_data/file/468003/horr81.pdf.

Sidebottom, A., Ashby, M., \& Johnson, S. D. (2014). Copper cable theft. Journal of Research in Crime and Delinquency, 51(5), 684-700. https:// doi.org/10.1177/0022427814521216

Sidebottom, A., Belur, J., Bowers, K., Tompson, L., \& Johnson, S. D. (2011). Theft in price-volatile markets: On the relationship between copper price and copper theft. Journal of Research in Crime and Delinquency, 48(3), 396-418. https://doi.org/10.1177/0022427810393021

Sutton, M. (1998). Handling stolen goods and theft: A market reduction approach. Research, Development and Statistics Directorate. Research Study 178. Home Office: London.

Tang, C. F., \& Lean, H. H. (2007). Will inflation increase crime rate? New evidence from bounds and modified Wald tests. Global Crime, 8(4), 311-323. https://doi.org/10.1080/17440570701739694

Thompson, R. (2017). Portable electronics and trends in goods stolen from the person. Journal of Research in Crime and Delinquency, 54(2), 276-298. https://doi.org/10.1177/0022427816660743

Tilley, N., \& Tseloni, A. (2016). Choosing and using statistical sources in criminology: What can the crime survey for England and Wales tell us? LIM, 16, 78 .
Tonry, M. (2014). Why crime rates are falling throughout the western world. Crime and Justice, 43(1), 1-63. https://doi.org/10.1086/678181

Wellsmith, M., \& Burrell, A. (2005). The influence of purchase price and ownership levels on theft targets: The example of domestic burglary. The British Journal of Criminology, 45(5), 741-764. https://doi.org/10. 1093/bjc/azi003

Welsh, B. C., \& Farrington, D. P. (1999). Value for money? A review of the costs and benefits of situational crime prevention. British Journal of Criminology, 39(3), 345-368.

Wright, R. T., \& Decker, S. H. (1996). Burglars on the job: Streetlife and residential break-ins. Northeastern University Press.

Yearwood, D. L., \& Koinis, G. (2011). Revisiting property crime and economic conditions: An exploratory study to identify predictive indicators beyond unemployment rates. The Social Science Journal, 48(1), 145-158. https:// doi.org/10.1016/j.soscij.2010.07.015

\section{Publisher's Note}

Springer Nature remains neutral with regard to jurisdictional claims in published maps and institutional affiliations.
Ready to submit your research? Choose BMC and benefit from:

- fast, convenient online submission

- thorough peer review by experienced researchers in your field

- rapid publication on acceptance

- support for research data, including large and complex data types

- gold Open Access which fosters wider collaboration and increased citations

- maximum visibility for your research: over $100 \mathrm{M}$ website views per year

At BMC, research is always in progress.

Learn more biomedcentral.com/submissions 